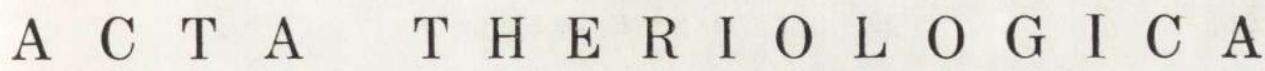 \\ VOL. 18, 22: $435-441$. \\ BIAEOWIEŻA \\ December, 1973
}

Stephen L. BAAR \& Eugene D. FLEHARTY

\section{A Respirometer for Determination of Metabolic Rates and Activity Patterns under Simulated Natural Conditions}

[With 1 Fig.]

\begin{abstract}
A metabolic chamber for continuously measuring bioenergetic parameters of small mammals is described. The apparatus consists of a nest box connected by a runway to an activity chamber that contains food, water, and an activity wheel. The nest box and activity chamber are maintained at temperatures commensurate with average burrow temperature and diel temperature cycle, respectively, for each week. Natural conditions of starlight, moonlight, twilight, and daylight are approximated. Oxygen consumption in the open system is measured by a Beckman polarizing oxygen analyzer and recorded on an analog recorder. Activity is constantly monitored on an event recorder through the use of two photoconductive cells in the runway to indicate movement between the nest box and activity chamber and by a microswitch on the activity wheel to indicate running; additionally, rotations of the wheel are totalled by an electric counter. The apparatus has proved to be successful in 24-hour determinations of both oxygen consumption and activity patterns under simulated natural conditions.
\end{abstract}

\section{INTRODUCTION}

Energy flow may be defined as the sum of the energy expended in maintenance of body functions plus that spent in growth. In mammals, about $98 \%$ of the energy flow is required for maintenance (see summary by Fleharty \& Choate, 1973); therefore, precise measurement of metabolic parameters associated with maintenance is necessary if one is to obtain an accurate estimate of energy flow. Chew \& $\mathrm{Ch}$ ew (1970) asserted that energy of maintenance equals energy expended by an animal when resting plus that used by the animal when active. Additionally, energy expended when inactive (either in or outside the nest) varies according to environmental temperature. Therefore, it is necessary to know four parameters in order to calculate the resting metabolic rate: (1) time spent in the nest, (2) temperature in the nest, (3) time spent at rest outside the nest, and (4) temperature outside the nest. To determine 
energy expended during periods of activity one must know how much time is spent in activity and the intensity of that activity ( $\mathrm{Chew}$ \& Chew, 1970). Activity periods doubtlessly are influenced by numerous variables, but two of the more important almost certainly are variations in intensity of light (daylight, starlight, or moonlight) and temperature (including both daily and seasonal fluctuations and the difference between the temperature in the nest and that outside the nest).

Historically, two methods have been used to estimate the average daily metabolic rate: (1) the food consumption method (energy balance), in which fecal and excretory energy loss is subtracted from total energy consumed ( $\mathrm{Brody}, 1945$; Odum, Connell, \& Davenport, 1962; Fleharty \& Choate, 1973), and (2) the oxygen consumption method, in which the amount of oxygen utilized is measured and converted to calories through the use of an oxy-caloric coefficient based on the respiratory quotient for the particular diet of the animal. Odum et al. (1962) and Golley (1967) suggested that the oxygen consumption method is less reliable than the food consumption method because determination of oxygen uptake is usually based on animals confined in small respirometers that restrict movement; metabolic rates determined under those circumstances are usually only about one-half of those determined by the food consumption method $(\mathrm{O} \mathrm{dum}$ et al., 1962; $\mathrm{Haberman} \mathrm{\&} \mathrm{Fleharty,} \mathrm{1971).} \mathrm{However,} \mathrm{McNab}$ (1963) pointed out that the oxygen consumption method is as accurate, if not more so, than the food consumption method when activity is taken into consideration.

Methods of determining oxygen uptake employ either a closed system (e.g., see Morrison, 1947; 1951; Pearson, 1947; G ębczyński, 1963) or an open system (Pauling, Wood \& Sturdivant, 1946; Depocas \& Hart, 1957). Polish researchers, who have contributed substantially to an understanding of energetics of small mammals (e.g. Grodziński \& Górecki, 1967; Górecki, 1968; 1969; Gębczyńska, 1970; Grodziński, 1971) have relied largely on the closed systems described by Morrison (1947) and Gębczyn $\mathrm{ski}$ (1963). Both of these respirometers include nest chambers and areas for activity [Morrison's (1947) respirometer originally was not equipped with an activity wheel, but one subsequently was added (Górecki, 1968)]. Additionally, both respirometers are designed so that photoperiod can be varied and so that measurements can be recorded continuously for over 24 hours.

However, there are two important sources of potential error in results obtained from animals maintained in those respirometers. First, both the nest and activity chamber are maintained at identical temperatures. As a result, any differences in temperature between the environments of the nest and the above ground habitat together with resultant differences in activity patterns and metabolic rates are ignored. To circumvent the problem of how to estimate changes in metabolic rate at temperatures in the nest and at those above ground, many researchers determine an average daily metabolic rate at the temperature of the nest (where an animal spends most of its life) and then correct for the metabolized energy of the animal when it is out of the nest by extrapolating from a thermoregulation curve based on the resting metabolic rate recorded at various temperatures (Grodziński \& Górecki, 1967). The second potential source of error has to do with the 
fact that experimental animals in a respirometer usually are maintained either at a 12 hour light-dark cycle ( $\mathrm{T} \mathrm{u}$ cker, 1965) or at conditions ssimilar to those of the natural rhythm" (G ębczyńska, 1970). As a result, intensity of light (which is known to influence patterns of activity - see Blair, 1943; Kavana u, 1962) generally is ignored.

Both of these potential sources of error would effect determination of metabolic rate by modifying normal patterns of activity of the experimental animals. In an attempt to more nearly approximate the true metabolic rates of small mammals during natural patterns of activity and under temperature regimes that normally confront them during any 24 hour period (Ryszkowski \& Petrusewicz, 1967), we designed a new type of respirometer. The advantages of the respirometer described below are, first, intensities of light can be regulated from starlight through daylight and, second, the nest box and the activity chamber can be maintained at temperatures commensurate with field conditions, thereby precluding the necessity of determining a thermoregulation curve to correct for metabolized energy produced at above-ground environmental temperatures.

\section{DESCRIPTION OF APPARATUS}

The metabolic chamber (Fig. 1) consists of two sections, a nest box $(10.2 \mathrm{~cm} \times 10.2 \mathrm{~cm} \times 12.7 \mathrm{~cm})$ and an activity chamber $(25.4 \mathrm{~cm} \times$ $\times 20.5 \mathrm{~cm} \times 45.7 \mathrm{~cm}$ ), each housed in separate Fischer Low Temperature Incubators and connected by a tubular runway $(5.1 \mathrm{~cm} \times 30.5 \mathrm{~cm})$. Nesting material is provided in the nest box and an activity wheel and sources of food and water are available in the activity chamber. The activity wheel is equipped with an on-off microswitch and mounted on a perforated $25.4 \mathrm{~cm} \times 30.5 \mathrm{~cm}$ plexiglass base. The plexiglass base and attached activity wheel are placed on a layer of "Drierite", which serves to remove excess water vapor in the chamber due to respiration and to evaporation from urine. Each revolution of the wheel closes and opens the microswitch, thereby registering one unit on an electric counter and one event on an event recorder. Two cadmium-selenium photoconductive cells are located $13.0 \mathrm{~cm}$ apart and perpendicular to the long axis of the runway. Beams of red light project across the runway at these places and illuminate the photocells. When an animal breaks one of these beams, a signal is recorded on the corresponding channel of a Rustrak Miniature Event Recorder. The photocells and activity wheel thus allow three aspects of activity to be recorded: 1) nonactive, in the nest box; 2) active, not running in wheel; 3) active, running in wheel.

The average diel temperature for each week is maintained in the activity chamber by periodically adjusting the temperature in the appropriate incubator. In like manner, the nest box is maintained at a temperature commensurate with that of a nest under field conditions by the other incubator. Temperatures in the nest and activity chamber are con- 
tinuously monitored by two Rustrak temperature probes, and recorded on one channel of a Rustrak dual-recording two-channel analog recorder.

A modified version of $\mathrm{K}$ a vana u's (1962) system provides quasinatural starlight, moonlight, dawn, daylight, and dusk. A 24-hour timeswitch governs the time of sunrise, sunset, and moonrise or moonset.

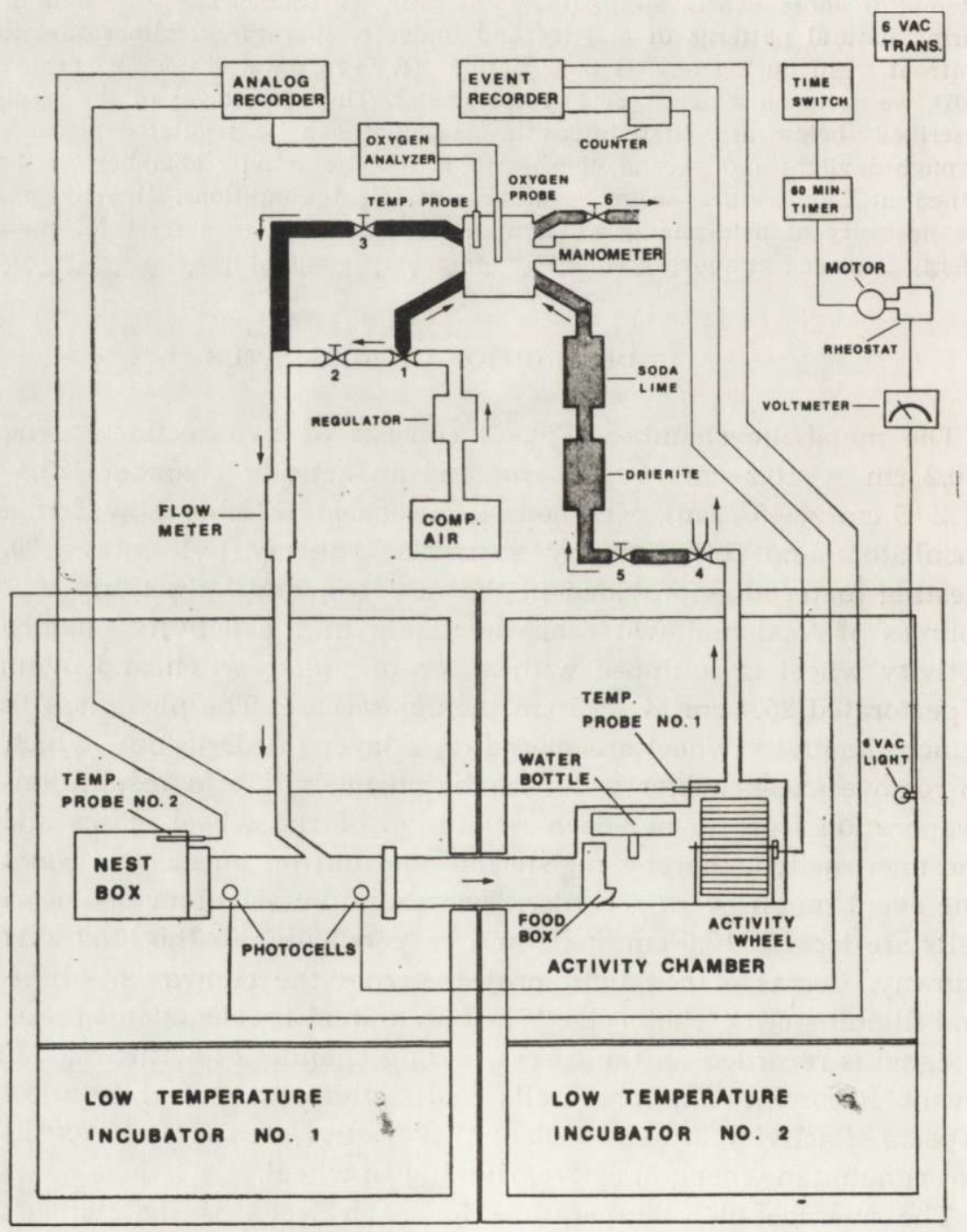

Fig. 1. Schematic diagram showing the respirometer, controls, and recorders used to determine average daily metabolic rates and activity patterns of small mammals. Arrows indicate direction of flow air. Specific path of air flow during each function is indicated by degree of shading: black, monitor only; gray, standardize only; white, used during both monitoring and standardizing. 
When the contacts of the timeswitch are closed, a 60-minute timer is activated; this timer controls the time a reversible motor geared to a 15 ohm rheostat will rotate. The setting of the timer and the direction of rotation of the rheostat dictates the change in illumination in the activity chamber that occurs when the timer is activated. The motor is geared to the rheostat so that 58 minutes are required for a full rotation from minimum to maximum resistance. At minimum resistance the light output corresponds to daylight, and at maximum resistance light intensity is equivalent to a clear, moonless night. Other light intensities (one-quarter moon, one-half moon, three-quarters moon, and full moon) lie between these two levels.

The animal is supplied air from a bottle of compressed gas $\left(21 \% \mathrm{O}_{2}\right.$, $79 \% \mathrm{~N}_{2}$ ) through a low pressure regulator. A Beckman polarizing oxygen analyzer is used to measure temperature and oxygen content of the outgoing air. Oxygen concentration is continuously recorded on a Rustrak analog recorder. The oxygen and temperature probes are housed in an airtight box, $5.1 \mathrm{~cm} \times 5.1 \mathrm{~cm} \times 12.7 \mathrm{~cm}$, submerged in a constant temperature water bath. Air pressure is measured by manometer connected to the box containing the oxygen probe. Airflow follows one of two possible paths depending on the operation, either monitoring or standardizing. When monitoring oxygen consumption, the following route is taken: ingoing air leaves the regulator, passes through valve one (open, valves two and three are closed) and the flowmeter, and enters the runway; outgoing air leaves the activity chamber, goes through a column of "Drierite " and one of soda lime, past valve five (open), and out of the system through valve six (open). Periodicaily the oxygen analyzer is standardized, using ingoing air as a reference by reversing the setting of the six valves. This setting directs ingoing air past the oxygen probe to the metabolic chamber and releases outgoing air through valve four.

We have made several determinations of average daily metabolic rate using the respirometer and attendant apparati described above, and we are convinced that the problems related both to the effects of light and to differences in temperature between nest and activity chamber on the activity of experimental animals are minimized.

Acknowledgements: We are grateful to Dr. Jerry R. Cho a te, Fort Hays Kansas State College, for his critical review of the manuscript, to Sherry $\mathrm{Qu}$ in t for help with the figure, and to Michael F. A rtman for assistance in construction of the apparatus.

\section{REFERENCES}

1. Blair F. W., 1943: Activities of the Chihuahua deer-mouse in relation to light intensity. J. Wildl. Mgt., 7: 92-97. 
2. Brody S., 1945: Bioenergetics and growth. Reinhold Publ. Co.: 1-1032. New York.

3. Chew R. M. \& Chew A. E., 1970: Energy relationships of the mammals of a desert shrub (Larrea tridentata) community. Ecol. Monographs 40: 1-21.

4. Depocas F. \& Hart J. S., 1957: Use of the Pauling oxygen analyzer for measurement of oxygen consumption of animals in open-circuit systems and in a short-lag, closed-circuit apparatus. J. Appl. Physiol., 10: 388-392.

5. Fleharty E. D. \& Choate J. R., 1973: Bioenergetic strategies of the cotton rat. Siamodon hispidus. J. Mammal., in print.

6. Gębczyńska Z., 1970: Bioenergetics of a root vole population. Acta theriol., 15, 3: $33-66$.

7. Gębczyński M., 1963: Apparatus for daily measurements of oxygen consumption in small mammals. Bull. Acad. Pol. Sci., Cl. II. 11, 9: 433-435.

8. Golley F. B., 1967: Methods of measuring secondary productivity in terrestrial vertebrate populations. [In: "Secondary productivity of terrestrial ecosystems«. Ed. K. Petrusewicz)]. 1: 295-314. Polish Sci. Publ. Warszawa-Kraków.

9. Górecki A., 1968: Metabolic rate and energy budget in the bank vole. Acta theriol., 13, 20: $341-365$.

10. Górecki A., 1969: Metabolic rate and energy budget of the striped field mouse. Acta theriol., 14, 14: 181-190.

11. Grodziński W. \& Górecki A., 1967: Daily energy budgets of small rodents: [In: "Secondary productivity of terrestrial ecosystems". Ed. K. Petrus ewicz]. 1: 295-314. Polish Sci. Publ. Warszawa-Kraków.

12. Grodziński W., 1971: Energy flow through populations of small mammals in the Alaskan taiga forest. Acta theriol., 16, 17: 231-275.

13. Haberman C. G. \& Fleharty E. D., 1971: Energy flow in Spermophilus franklinii. J. Mammal., 52: 710-716.

14. Kavana u J. L., 1962: Twilight transitions and biological rhythmicity. Nature, 194: 1293-1295.

15. M c N a b B. K., 1963: A model of the energy budget of a wild mouse. Ecology, 44: $521-532$.

16. Morrison P. R., 1947: An automatic apparatus for the determination of oxygen consumption. J. Biochem., 169: 667-679.

17. Morrison P. R., 1951: An automatic manometric respirometer. Rev. Sci. Instr., 22: $264-267$.

18. Odum E. P., Connell C. E. \& Davenport L. B., 1962: Population energy flow of the primary consumer components of old-field ecosystems. Ecology, 43, 1: 88-96.

19. Pauling L., Wood R. E. \& Sturdivant J. H., 1946: An instrument for determining the partial pressure of oxygen in a gas. J. Am. Chem. Soc., 68: $795-798$.

20. Pearson O. P., 1947: The rate of metabolism of some small mammals. Ecology, 28: 127-145.

21. Ryszkowski L. \& Petrusewicz K., 1967: Estimation of energy flow through small rodent populations. [In: "Secondary productivity of terrestrial ecosystems«. Ed. K. Petrusewicz]. 1: 125-146. Polish Sci. Publ. Warszawa-Kraków. 
22. Tucker V. A., 1965: Oxygen consumption, thermal conductance, and torpor in the California pocket mouse Perognathus californicus. J. Cell. and Comp. Physiol., 65: 393-403.

Accepted June 20, 1973.

Department of Biological Sciences, Museum of the High Plains, Fort Hays, Kansas State College, Hays, Kansas, 67601 U.S.A.

\section{S. L. BAAR i E, D. FLEHARTY}

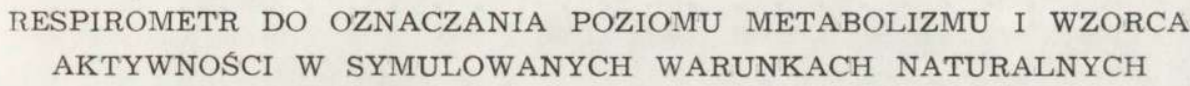

\section{Streszczenie}

Opisano aparat służący do ciągłego pomiaru niektórych wskaźników bioenergetycznych u małych ssaków. Przyrząd ten składa się z części gniazdowej połączonej korytarzem z wybiegiem, na którym zwierzę ma dostęp do pokarmu, wody i ruchomego bębna (Ryc. 1). W części gniazdowej można utrzymywać temperaturę taką jaka panuje w norach a równocześnie na wybiegu naśladować jej naturalny cykl. Możliwe jest też symulowanie naturalnych warunków oświetlenia właściwych zarówno dla dnia jak i noey. Pomiary zużycia tlenu oparte na zasadzie systemu otwartego, dokonywane są przy użyciu analizatora firmy Beckman a jego wskazania są automatycznie rejestrowane. Zapisywana jest też aktywność dzięki zainstalowaniu fotokomórek w korytarzu łączącym wybieg $\mathrm{z}$ gniazdem. Dodatkowo notowane są ruchy bębna w którym mogą biegać badane zwierzęta. Przydatność opisanego aparatu sprawdzono w pomiarach całodobowych. 


\section{STRUCTURE, FUNCTIONING AND MANAGEMENT OF ECOSYSTEMS}

The First International Congress of Ecology will be held in The Hague, The Netherlands, between 8 and 14 September 1974.

The main purpose of the Congress will be to bring together ecologists from all disciplines to discuss unifying concepts. Besides a number of special symposia will be held, partly organized by the International Biological Programme. The themes are:

-- Flow of energy and matter between trophic levels.

- Comparative productivity in ecosystems.

- Diversity, stability and maturity in natural ecosystems.

- Diversity, stability and maturity in ecosystems influenced by human activities.

- Strategies for management of natural and man-made ecosystems.

-- The significance of ecological principles for society.

Information: Secretariat First International Congress of Ecology P.O. Box 9000

The Hague

The Netherlands. 